J. Dairy Sci. 95:7409-7416

http://dx.doi.org/10.3168/jds.2012-5340

(C) American Dairy Science Association ${ }^{\circledR}, 2012$.

\title{
Emissions of ammonia, nitrous oxide, methane, and carbon dioxide during storage of dairy cow manure as affected by dietary forage-to-concentrate ratio and crust formation
}

\author{
M. J. Aguerre, ${ }^{*}$ M. A. Wattiaux, ${ }^{* 1}$ and J. M. Powell† \\ *Department of Dairy Science, University of Wisconsin-Madison 53706 \\ †USDA-Agricultural Research Service, US Dairy Forage Research Center, Madison, WI 53706
}

\begin{abstract}
Sixteen 200-L barrels were used to determine the effects of dietary forage-to-concentrate $(\mathrm{F}: \mathrm{C})$ ratio on the rate of $\mathrm{NH}_{3}-\mathrm{N}, \mathrm{N}_{2} \mathrm{O}, \mathrm{CH}_{4}$, and $\mathrm{CO}_{2}$ emissions from dairy manure during a 77 -d storage period. Manure was obtained from a companion study where cows were assigned to total mixed rations that included the following F:C ratio: 47:53, 54:46, 61:39, and 68:32 (diet dry matter basis) and housed in air-flow-controlled chambers constructed in a modified tiestall barn. On d 0 of this study, deposited manure and bedding from each emission chamber was thoroughly mixed, diluted with water (1.9 to 1 manure-to-water ratio) and loaded in barrels. In addition, on d $0,7,14,28,35,49,56,63,70$, and 77 of storage, the rate of $\mathrm{NH}_{3}-\mathrm{N}, \mathrm{N}_{2} \mathrm{O}, \mathrm{CH}_{4}$, and $\mathrm{CO}_{2}$ emissions from each barrel were measured with a dynamic chamber and gas concentration measured with a photoacoustic multi-gas monitor. Data were analyzed as a randomized complete block with 4 replications. Dietary $\mathrm{F}: \mathrm{C}$ ratio had no effect on manure dry matter, total $\mathrm{N}$ and total ammoniacal- $\mathrm{N}\left(\mathrm{NH}_{3}-\mathrm{N}+\mathrm{NH}_{4}{ }^{+}-\mathrm{N}\right)$, or $\mathrm{pH}$ at the time of storage (mean \pm SD: $10.6 \pm 0.6 \%, 3.0 \pm$ $0.2 \%, 93.1 \pm 18.1 \mathrm{mg} / \mathrm{dL}$, and $7.8 \pm 0.5$, respectively). No treatment differences were observed in the overall rate of manure $\mathrm{NH}_{3}-\mathrm{N}, \mathrm{N}_{2} \mathrm{O}, \mathrm{CH}_{4}$, and $\mathrm{CO}_{2}$ emissions (mean $\pm \mathrm{SD}$ over the 77 -d storage period; $117 \pm 25$, $30 \pm 7,299 \pm 62$, and $15,396 \pm 753 \mathrm{mg} / \mathrm{hr}$ per $\mathrm{m}^{2}$, respectively). The presence of straw bedding in manure promoted the formation of a surface crust that became air dried after about 1 mo of storage, and was associated with an altered pattern in $\mathrm{NH}_{3}-\mathrm{N}$ and $\mathrm{N}_{2} \mathrm{O}$ emissions in particular. Whereas $\mathrm{NH}_{3}-\mathrm{N}$ emission rate was highest on d 0 and gradually decreased until reaching negligible levels on d 35, $\mathrm{N}_{2} \mathrm{O}$ emission rate was almost zero the first 2 wk of storage, increased sharply to peak on $\mathrm{d} 35$, and decreased subsequently. The emission rate
\end{abstract}

Received January 12, 2012.

Accepted August 11, 2012.

${ }^{1}$ Corresponding author: wattiaux@wisc.edu of $\mathrm{CH}_{4}$ and $\mathrm{CO}_{2}$ peaked simultaneously on $\mathrm{d} 7$, but decreased subsequently until the end of the storage period. In this study, C:N ratio of gaseous losses was 32:1, reflecting higher volatile $\mathrm{C}$ loss than volatile $\mathrm{N}$ loss during storage. On a $\mathrm{CO}_{2}$-equivalent basis, the most important source of non- $\mathrm{CO}_{2}$ greenhouse gas emitted was $\mathrm{CH}_{4}$ until formation of an air-dried crust, but $\mathrm{N}_{2} \mathrm{O}$ thereafter. Taken together, these results suggested that the formation of an air-dried crust resulting from the straw bedding present in the manure reduced drastically $\mathrm{NH}_{3}-\mathrm{N}$, and $\mathrm{CH}_{4}$ emissions, but was conducive of $\mathrm{N}_{2} \mathrm{O}$ production and emission.

Key words: ammonia, nitrous oxide, methane, manure

\section{INTRODUCTION}

National (NRC, 2003; EPA 2009) and international (FAO, 2006) reports have concluded that animal feeding operations are important sources of undesirable gaseous emissions that affect natural ecosystems and human health $\left(\mathrm{NH}_{3}\right)$ and contribute to emissions of non- $\mathrm{CO}_{2}$ greenhouse gases $\left(\mathrm{CH}_{4}\right.$ and $\left.\mathrm{N}_{2} \mathrm{O}\right)$. Although several strategies have been evaluated for reducing emission of $\mathrm{NH}_{3}$ (Ndegwa et al., 2008; VanderZaag et al., 2008) and non- $\mathrm{CO}_{2}$ greenhouse gases (Benchaar et al. 2001; Boadi et al., 2004; Martin et al., 2010), few of the proposed mitigation strategies so far have emerged from experiments in which multiple gases were measured simultaneously (Külling et al., 2001). In addition, most studies have tended to compartmentalize gaseous emissions at either the housing and collection subsystem, the storage subsystem, or the field application subsystem. Few studies have crossed subsystem boundaries (Amon et al., 2001).

Results from a companion study (Aguerre et al., 2011) designed to determine the effects of forage-toconcentrate $(\mathbf{F}: \mathbf{C})$ ratios in the diet on cow performance and gaseous emission showed that increasing forage concentration from 47 to $68 \%$ of DM in isonitrogenous diets increased $\mathrm{CH}_{4}$ emission per unit of ECM by $25 \%$ 
but did not alter $\mathrm{NH}_{3}-\mathrm{N}$ emission when cows were housed in a tiestall barn. The objective of this study was to determine the effects of $\mathrm{F}$ : $\mathrm{C}$ ratios in the diet on gaseous emission during manure storage. Thus, the pattern of change in volatile $\mathrm{C}$ loss $\left(\mathrm{CO}_{2}\right.$ and $\left.\mathrm{CH}_{4},\right)$ and volatile $\mathrm{N}$ loss $\left(\mathrm{NH}_{3}\right.$ and $\left.\mathrm{N}_{2} \mathrm{O}\right)$ during a 77 -d storage period was determined using the manure and bedding collected from cows in the companion study.

\section{MATERIALS AND METHODS}

\section{Manure Storage, Sampling, and Analyses}

The manure and bedding used in this trial was collected from a companion study (Aguerre et al., 2011). Briefly, 16 lactating Holstein cows were assigned to 1 of 4 air-flow controlled chambers (4 cows per chamber) constructed in a modified tiestall barn and, in turn, chambers were assigned to a sequence of 4 dietary treatments in a single $4 \times 4$ Latin square design, with 21-d periods. Dietary treatments, fed as TMR, included the following F:C ratio: 47:53, 54:46, 61:39, and 68:32 (DM basis). Dietary CP was similar among treatments and averaged $16.2 \%$ (DM basis). In contrast, as the F:C ratio increased from 47:53 to 68:32, NDF concentration increased from 31.3 to $38.3 \%$ of dietary DM, forage NDF (percentage of total NDF) increased from 68 to $79 \%$, and starch concentration decreased from 29 to $20 \%$ of dietary DM. Cows were bedded on rubber mats with daily addition of wheat straw as bedding. Details of animal management, diet composition, animal performance, and gaseous emission data from the air-flow controlled chambers were described elsewhere (Aguerre et al., 2011).

During the last day of each period, deposited manure and bedding from each emission chamber was allowed to accumulate for $8 \mathrm{~h}$. While cows were in the milking parlor, accumulated manure (including bedding deposited in the collection pans) was weighed using a bench scale (Ohaus ES Series Bench Scale; Ohaus Co, Pine Brook, NJ), loaded in 200-L barrels (90 and 61 $\mathrm{cm}$ in height and diameter, respectively), and diluted with water (1.9 to 1 manure-to-water ratio) to lower DM content to a range typically found in liquid manure (Rotz, 2004). Overall, the amount of manure-straw mixture and water added to a barrel averaged $( \pm \mathrm{SD})$ $114 \pm 13$ and $61 \pm 7 \mathrm{~kg}$, respectively. The average $( \pm \mathrm{SD})$ estimated amount of straw bedding (0.81 \pm $0.17 \% \mathrm{~N}$ and $71 \pm 0.7 \% \mathrm{NDF}$ ) in the manure was $2.4 \pm$ $0.7 \mathrm{~kg}$, as calculated by difference between the amount of bedding added and recovered from the chamber.

The day the barrels were loaded (d 0), manure samples were collected from each barrel, preserved with $60 \%$ sulfuric acid, and stored at $-20^{\circ} \mathrm{C}$. Before acidification, $\mathrm{pH}$ of a deionized water/manure mixture (2:1 ratio) was measured using a calibrated portable pH meter (Twin pH-meter model B-213; Spectrum Technologies Inc., Plainfield, IL). Manure samples were thawed at $5{ }^{\circ} \mathrm{C}$ overnight and lyophilized in a Frezone 12 freeze dryer (Labonco Corp., Kansas City, MO). Before lyophilization, an acidified manure subsample was extracted with a $2 \mathrm{M} \mathrm{KCl}$ solution (Misselbrook et al., 2005) for total ammoniacal-N (TAN $=\mathrm{NH}_{3}-\mathrm{N}+$ $\mathrm{NH}_{4}{ }^{+}-\mathrm{N}$ ) determination by colorimetric assay (Chaney and Marbach, 1962). Lyophilized manure samples were ground through a 1-mm Wiley mill screen (Arthur H. Thomas Co., Philadelphia, PA) and analyzed for total N content (TN; Leco FP-2000 nitrogen analyzer; Leco Instruments Inc., St. Joseph, MI) and analytical DM at $105^{\circ} \mathrm{C}$ for $24 \mathrm{~h}$. Manure DM content was calculated as the amount of sample recovered after lyophilization. Neutral detergent fiber content was determined according to Van Soest et al. (1991) and adapted for an Ankom ${ }^{200}$ fiber analyzer (Ankom Technology Corp., Fairport, NY), using $\alpha$-amylase (Sigma no. A3306; Sigma Chemical Co., St. Louis, MO) and sodium sulfite and corrected for ash concentration. Manure starch content was analyzed commercially (Dairyland Laboratories Inc., Arcadia, WI) using wet chemistry analysis (Bach-Knudsen, 1997). Furthermore, $\mathrm{pH}$ was measured on samples collected on $\mathrm{d} 77$ following the procedure described above.

\section{Gas Emissions Measurement}

Each of the 4 barrels filled with manurial treatment at the end of each period of the $4 \times 4$ Latin Square design and a blank barrel with no manure were stored with no covering lid in an open-storage room located near the barn entrance, where temperature control was not possible. A 77-d storage period was chosen to avoid the effect of low seasonal temperature on emissions measurements. Four dynamic chambers were used to measure gas emission from each of the 4 groups of staggered barrels over a 1-h period on d $0,7,14$, $28,35,49,56,63,70$, and 77 of storage following a procedure adapted from Misselbrook et al. (2005). A fifth dynamic chamber was used for the blank barrel. Thus, gas emission measurements were conducted over 140 d. Modified circular lids with a centrally located fan (model DB200; Suncourt Inc., Durant, IA; 0.10-m diameter) drew air across the manure surface through 4 inlet holes (0.025-m diameter) cut at regular intervals around the perimeter of the lid. Overall, the headspace (mean height between stored manure and the lid) was $22 \pm 7 \mathrm{~cm}$ (mean $\pm \mathrm{SD}$ ). With increasing days of sampling, a general increase in the headspace occurred due to water and DM loss. Thus, headspace depth was 
measured before starting each emission measurement. Based on the changes in headspace depth, central duct fans were regulated to obtain an air velocity across the manure surface of approximately $0.06 \mathrm{~m} / \mathrm{s}$ and approximately 13 headspace changes per minute. Five cross-sectional samplers were constructed with Teflon tubing (Nalgene, Rochester, NY) to sample the air that passed through the headspace of the manure storage. Each sampler consisted of 4 round arms that cover the entire circumference of the fan. On each arm, 4 sampling holes were drilled at equal distance from the center of the sampler. Air samples were drawn through Teflon tubing (6.4-mm o.d., 4.8-mm i.d.; Nalgene) connected to a Whatman Hepa-Vent Filter (Fischer Scientific, Pittsburgh, PA). Air samples were sequentially drawn from each of the 5 samplers using a computercontrolled sequencer (Mark 3 Intelligent Sampler; California Analytical Instruments Inc., Orange, CA) and analyzed for $\mathrm{NH}_{3}, \mathrm{~N}_{2} \mathrm{O}, \mathrm{CH}_{4}$, and $\mathrm{CO}_{2}$ concentration with a manufactured-calibrated photo-acoustic multigas monitor (Innova model 1412; AirTech Instruments A/S, Ballerup, Denmark). The sequencer continuously collected an air sample from a barrel during $60 \mathrm{~s}$ to flush sampling tubing. Then, it sent an air sample to the gas analyzer and flushed the analyzer measurement chamber for 55 s. Finally, a single concentration (parts per million volume, ppmv) was measured sequentially for each gas in a 29-s period (a total sampling time for a single barrel of $2 \mathrm{~min}$ and 24s). As a result, air from each barrel was sampled once every 12 min. Measurements from the blank barrels were used to account for background gaseous concentrations. Concentration (g/ $\mathrm{m}^{3}$ ) of the measured gases was calculated with the following equation:

$$
\mathrm{G}=\left(\mathrm{C}_{\mathrm{o}}-\mathrm{C}_{\mathrm{i}}\right) \times 1,000 \times \mathrm{MW} / \mathrm{V} \times 1 / 1,000,000,
$$

where $\mathrm{G}$ is the gas concentration in the outlet air ( $\mathrm{g} /$ $\left.\mathrm{m}^{3}\right) ; \mathrm{C}_{\mathrm{o}}$ is the concentration of the gas in the outlet air (ppmv); $\mathrm{C}_{\mathrm{i}}$ is the concentration of the gas in the inlet air (outlet air of blank barrel; ppmv); MW is the molecular weight of the gas $(16.04,17.03,44.01$, and 44.01 $\mathrm{g} / \mathrm{mol}$ for $\mathrm{CH}_{4}, \mathrm{NH}_{3}, \mathrm{CO}_{2}$, and $\mathrm{N}_{2} \mathrm{O}$, respectively); and $\mathrm{V}$ is the volume occupied by $1 \mathrm{~mol}$ of gas at the measured air temperature and pressure (L), obtained from a weather station in Prairie Du Sac, WI (accessed from http://Wunderground.com).

Air velocity and temperature through the central duct of the lid was measured using a hand-held rotating vane anemometer with a temperature sensor (model 8324 VelociCalc Plus; TSI Inc., Shoreview, MN). The volume of air though the central duct during each sampling interval $\left(\mathrm{m}^{3} / 12 \mathrm{~min}\right)$ was calculated as the product of the air velocity through the central duct $(\mathrm{m} /$ $\min )$ and the surface area of the duct $\left(\mathrm{m}^{2}\right)$.

Amount of gas emitted (g) during each of the 12-min sampling intervals was calculated as the product of gas concentration in the outlet air $\left(\mathrm{g} / \mathrm{m}^{3}\right)$ and the volume of air passing through $\left(\mathrm{m}^{3} / 12 \mathrm{~min}\right)$. The emission rate from the manure surface $\left(\mathrm{g} / \mathrm{h}\right.$ per $\left.\mathrm{m}^{2}\right)$ was calculated by adding up the gas emitted at each of the five 12-min sampling intervals in the 1 -h collection period $(\mathrm{g} / \mathrm{h})$ and expressed per square meter of surface area. In addition, emissions of $\mathrm{CH}_{4}$ and $\mathrm{N}_{2} \mathrm{O}$ were calculated as $\mathrm{CO}_{2}$ equivalents, for a 100-yr time horizon, using a factor of 25 and 298 for $\mathrm{CH}_{4}$ and $\mathrm{N}_{2} \mathrm{O}$, respectively (IPCC, 2007). The global warming potential was calculated as the sum of $\mathrm{CO}_{2}$ equivalents emitted as $\mathrm{CH}_{4}$ and $\mathrm{N}_{2} \mathrm{O}$. These emission measurements and calculations were used for treatment comparison and not as an attempt to determine emission factors. Gas emissions measured and reported here do not capture the numerous factors affecting gas emissions from manure storage on commercial farms.

\section{Statistical Analyses}

The experiment was conducted as a randomized complete block with 4 replicate and repeated measures. Manure composition on d 0 was analyzed with the mixed procedure in SAS (SAS Institute, 2004) with the following model:

$$
\mathrm{Y}_{\mathrm{ijk}}=\mu+\mathrm{B}_{\mathrm{i}}+\mathrm{D}_{\mathrm{j}}+\mathrm{e}_{\mathrm{ijk}}
$$

where $Y_{\mathrm{ijk}}$ is the dependent variable, $\mu$ is the overall mean, $B_{i}$ is the effect of block ( $i=1$ to 4$), D_{j}$ is the effect of diet ( $\mathrm{j}=1$ to 4$)$, and $\mathrm{e}_{\mathrm{ijk}}$ is the residual error. All terms were considered fixed except for block and residual error.

For repeated measures including $\mathrm{NH}_{3}-\mathrm{N}, \mathrm{CO}_{2}, \mathrm{CH}_{4}$, and $\mathrm{N}_{2} \mathrm{O}$ emission rates, the above model was expanded to include effect of day of storage and interaction between treatment and day of storage. All terms were considered fixed except for block and residual error. Due to heterogeneous variance across treatments, the first-order heterogeneous autoregressive covariance structure was used to fit the models (SAS Institute, 2004). To comply with the assumptions of normality and homoscedacity of residuals, gaseous emission rates were subjected to logarithmic transformation before statistical analysis. For these variables, reported arithmetic mean and standard error were from untransformed values, whereas $P$-values reflect statistical analysis of transformed data. 
Preplanned orthogonal contrasts were used to test for linear and quadratic effects of treatments. Significance was declared for $P \leq 0.05$ and tendency for $0.05<P$ $\leq 0.10$. No interaction was observed between treatment and day of storage for any of the measured gases and results are presented as daily means.

\section{RESULTS AND DISCUSSION}

\section{Manure Composition}

Reported chemical components of manurial treatments (i.e., the mixture of feces, urine, diluting water, and straw) on $\mathrm{d} 0$ were not influenced by the diet fed to the cows (Table 1). In contrast, Broderick (2003) reported higher manure $\mathrm{TN}$ excretion in isonitrogenous diets with increasing NDF content. Visual observation indicated that a crust started to form for all manurial treatments after $7 \mathrm{~d}$ of storage and the crust surface became dry between d 14 and 28; however, neither thickness nor moisture measurements were conducted to further characterize the crust. On d 77, a tendency $(P=0.10)$ was observed for a linear increase in manure $\mathrm{pH}$ as dietary forage increased $(6.63,6.75,6.77$, and 6.98 for $\mathrm{F}: \mathrm{C}$ ratio of $47: 53,54: 46,61: 39$, and $68: 32$, respectively).

\section{Ammonia-N Emission}

Under the conditions of this trial, the 77-d average $\mathrm{NH}_{3}-\mathrm{N}$ emission rate (Table 2) did not differ among treatments (mean $\pm \mathrm{SD} ; 117 \pm 25 \mathrm{mg} / \mathrm{h}$ per $\mathrm{m}^{2}$ ). Similarly, varying the dietary F:C ratio had no effect on short-term manure $\mathrm{NH}_{3}-\mathrm{N}$ emissions from a barn floor (Lascano et al., 2008) or under controlled laboratory conditions (Agle et al. 2010). The absence of differences in rate of $\mathrm{NH}_{3}-\mathrm{N}$ emissions among treatments was expected in part because of small differences in the initial amount of $\mathrm{N}$ placed in each barrel (Table 1) and no difference in TAN (mg/dL), TN (\% of DM), and $\mathrm{pH}$ among treatments on d 0 of storage (Table 1 ). The tendency for a difference in $\mathrm{pH}$ among dietary treatments on $\mathrm{d} 77$ could have affected the proportion of $\mathrm{NH}_{3} / \mathrm{NH}_{4}{ }^{+}$in the solution but any repercussion on $\mathrm{NH}_{3}-\mathrm{N}$ emission rate may have been curtailed after crust formation (Figure 1a). Ammonia-N emission rate was highest on d 0 (852 $\pm 404 \mathrm{mg} / \mathrm{h}$ per $\mathrm{m}^{2}$ ), but was $76 \%$ lower on $\mathrm{d} 7$, and gradually decreased to reach negligible levels on d 35 and thereafter (Figure 1a). These results were consistent with those of Aguerre et al. (2012) who observed a sharp decreased in $\mathrm{NH}_{3}$ emission within the first 12 $\mathrm{d}$ of storage associated with a reduction in manure $\mathrm{pH}$ as a result of VFA formation from OM fermentation. In addition, de Bode (1991) reported that undisturbed manure with a high DM content formed a crust after 10 to $20 \mathrm{~d}$ of storage. Furthermore, the peak in $\mathrm{CH}_{4}$ and $\mathrm{CO}_{2}$ emission observed in this trial (Figure 1c and 1d) supported the results of Misselbrook et al. (2005), suggesting that an air-dried crust of undigested fiber forms after gas bubble formation $\left(\mathrm{CO}_{2}\right.$ and $\left.\mathrm{CH}_{4}\right)$ and carries suspended particles to the surface. Interestingly, this process may be similar to the one responsible for stratification of ruminal content, whereby the specific gravity of fiber particles is lowered during fermentation (Wattiaux et al., 1991) thus contributing to the formation of a fibrous mat in the dorsal rumen. In short, the $\mathrm{NH}_{3}-\mathrm{N}$ emission reduction observed in this study is likely due to a reduction in manure $\mathrm{pH}$ during the first days of storage and the increase in transport resistance at the air-liquid interface once the crust was formed

Table 1. Composition of manure ${ }^{1}$ obtained from cows fed different dietary forage-to-concentrate (F:C) ratios and amounts added to storage barrels on $\mathrm{d} 0(\mathrm{n}=4)$

\begin{tabular}{|c|c|c|c|c|c|c|c|}
\hline \multirow[b]{2}{*}{ Item $^{2}$} & \multicolumn{4}{|c|}{ Dietary F:C ratio (DM basis) } & \multirow[b]{2}{*}{ SEM } & \multicolumn{2}{|c|}{$P$-value ${ }^{3}$} \\
\hline & $47: 53$ & $54: 46$ & $61: 39$ & $68: 32$ & & $\mathrm{~L}$ & $\mathrm{Q}$ \\
\hline DM, $\%$ as is & 10.6 & 10.9 & 10.7 & 10.3 & 0.35 & 0.44 & 0.33 \\
\hline $\mathrm{TN}, \%$ of $\mathrm{DM}$ & 3.10 & 3.05 & 2.95 & 2.96 & 0.10 & 0.20 & 0.77 \\
\hline TAN, mg/dL & 85.9 & 100.1 & 97.5 & 88.7 & 9.52 & 0.87 & 0.20 \\
\hline Starch, \% of DM & 1.76 & 1.57 & 1.41 & 1.36 & 0.19 & 0.14 & 0.72 \\
\hline $\mathrm{NDF}, \%$ of DM & 40.2 & 41.0 & 41.3 & 41.1 & 0.89 & 0.45 & 0.56 \\
\hline $\mathrm{pH}$ & 7.7 & 7.6 & 8.0 & 8.0 & 0.25 & 0.20 & 0.95 \\
\hline $\mathrm{DM}, \mathrm{kg}$ & 18.5 & 19.3 & 18.7 & 18.1 & 1.4 & 0.53 & 0.34 \\
\hline TN, g & 574 & 585 & 554 & 538 & 52.2 & 0.29 & 0.64 \\
\hline TAN, $g$ & 152 & 175 & 170 & 154 & 17.9 & 0.98 & 0.22 \\
\hline Starch, g & 329 & 303 & 260 & 246 & 49.8 & 0.17 & 0.90 \\
\hline NDF, $g$ & 7,451 & 7,899 & 7,723 & 7,429 & 589.5 & 0.87 & 0.29 \\
\hline
\end{tabular}

${ }^{1}$ Mixture of feces, urine, straw bedding, and diluting water.

${ }^{2} \mathrm{TN}=$ total $\mathrm{N} ; \mathrm{TAN}=$ total ammoniacal-N.

${ }^{3}$ Probability of a linear (L) or quadratic (Q) effect of F:C ratio level in the diet. 
Table 2. Arithmetic means (with $\mathrm{SE}$ in parentheses) of the 1- $\mathrm{h} \mathrm{NH}_{3}-\mathrm{N}, \mathrm{CH}_{4}, \mathrm{~N}_{2} \mathrm{O}$, and $\mathrm{CO}_{2}$ manure ${ }^{1}$ emission rates measured at different days of storage (d $0,7,14,28,35,49,56,63,70$, and 77$)$ when obtained from cows fed diets with different forage-to-concentrate (F:C) ratios

\begin{tabular}{|c|c|c|c|c|c|c|}
\hline \multirow[b]{2}{*}{ Item } & \multicolumn{4}{|c|}{ Dietary F:C ratio (DM basis) } & \multicolumn{2}{|c|}{$P$-value ${ }^{2}$} \\
\hline & $47: 53$ & $54: 46$ & $61: 39$ & $68: 32$ & $\mathrm{~L}$ & $\mathrm{Q}$ \\
\hline $\mathrm{NH}_{3}-\mathrm{N}, \mathrm{mg} / \mathrm{h}$ per $\mathrm{m}^{2}$ & $120(47)$ & $92(35)$ & $150(58)$ & $104(37)$ & 0.82 & 0.61 \\
\hline $\mathrm{CH}_{4}, \mathrm{mg} / \mathrm{h}$ per m${ }^{2}$ & $365(97)$ & $277(65)$ & $330(78)$ & $224(66)$ & 0.54 & 0.48 \\
\hline $\mathrm{N}_{2} \mathrm{O}, \mathrm{mg} / \mathrm{h}$ per $\mathrm{m}^{2}$ & $40(10)$ & $22(5)$ & $28(7)$ & $31(8)$ & 0.48 & 0.53 \\
\hline $\mathrm{CO}_{2}, \mathrm{mg} / \mathrm{h}$ per $\mathrm{m}^{2}$ & $15,490(2,110)$ & $15,572(2,561)$ & $16,162(2,792)$ & $14,360(2,491)$ & 0.77 & 0.85 \\
\hline $\mathrm{CH}_{4}\left(\mathrm{CO}_{2} \mathrm{Eq}\right), \mathrm{g} / \mathrm{h}$ per $\mathrm{m}^{2}$ & $9(2)$ & $7(2)$ & $8(2)$ & $9(3)$ & 0.74 & 0.81 \\
\hline
\end{tabular}

${ }^{1}$ Mixture of feces, urine, bedding straw, and diluting water.

${ }^{2}$ Probability of a linear (L) or quadratic (Q) effect of F:C ratio level in the diet.

(VanderZaag et al., 2008). In addition, the air-dried crust may reduce surface $\mathrm{pH}$, decreasing the proportion of TAN in the form of $\mathrm{NH}_{3}$ (Xue et al., 1999). Finally, the presence of $\mathrm{NH}_{3}$-oxidizing bacteria in organic crusts (Hansen et al., 2009; Nielsen et al. 2010) may reduce the emission of $\mathrm{NH}_{3}$ but be conducive to greater $\mathrm{N}_{2} \mathrm{O}$ losses. Long-term reduction in $\mathrm{NH}_{3}$ emission could be associated also with changes in the pool of labile $\mathrm{N}$ as a result of ongoing fermentation as time progress during storage (Sommer et al., 2006).

\section{Nitrous Oxide Emission}

Feeding varying $\mathrm{F}$ : $\mathrm{C}$ ratios to dairy cows had no effect on rate of $\mathrm{N}_{2} \mathrm{O}$ emission during manure storage (Table 2 ). For all treatments, $\mathrm{N}_{2} \mathrm{O}$ emission rates were barely detectable during the first $2 \mathrm{wk}$ of storage, but increased sharply on d 28, reached a peak on d 35 , and decreased subsequently until the end of the study (Figure 1b). This pattern was in agreement with a previous study in which an organic crust was established compared with no $\mathrm{N}_{2} \mathrm{O}$ of emission in the absence of a crust (Sommer et al. 2000). As reviewed by Kebreab et al. (2006), $\mathrm{N}_{2} \mathrm{O}$ is an intermediate product of both nitrification and denitrification processes that take place during manure storage. Hansen et al. (2009) and Nielsen et al. (2010) showed that drying of organic crust resulted in the formation of both oxic and anoxic zones and although dissolved TAN could be oxidized through nitrification into nitrite $\left(\mathrm{NO}_{2}{ }^{-}\right)$and then nitrate $\left(\mathrm{NO}_{3}{ }^{-}\right)$in the presence of oxygen, these products can be subsequently reduced under anoxic conditions to $\mathrm{N}_{2}$ by denitrification. However, incomplete reduction gives rise to higher concentrations of $\mathrm{N}_{2} \mathrm{O}$ and other volatile oxides of nitrogen. The gradual decrease in $\mathrm{N}_{2} \mathrm{O}$ emission rate from $\mathrm{d} 35$ to 77 of storage reported here suggested that subtle changes in crust environment may have important consequences. As storage progressed, increased moisture associated with crust deterioration may have reduced oxygen supply and, thus, $\mathrm{NO}_{2}^{-}, \mathrm{NO}_{3}{ }^{-}$, and $\mathrm{N}_{2} \mathrm{O}$ formation through nitrification. In turn, the depletion of denitrification reactants $\left(\mathrm{NO}_{2}{ }^{-}\right.$and $\left.\mathrm{NO}_{3}{ }^{-}\right)$may have contributed to reducing $\mathrm{N}_{2} \mathrm{O}$ emission. Although crust DM was not recorded in our study, others have shown that $\mathrm{N}_{2} \mathrm{O}$ emission was favored by low crust moisture content (Sommer et al., 2000; Hansen et al., 2009).

\section{Methane Emission}

No differences in $\mathrm{CH}_{4}$ emission among dietary treatments were observed during storage (Table 2). These results are consistent with the lack of difference in starch and fiber in the manure (Table 1). The same dietary treatments, however, had a major effect on enteric $\mathrm{CH}_{4}$ emission from dairy cows (Aguerre et al. 2011). In contrast to our results, Lodman et al. (1993) reported a higher $\mathrm{CH}_{4}$ emission rate from stored manure excreted by steers fed a high-grain diet (85\% of diet DM) compared with a $100 \%$ forage diet. In the present study, straw bedding could have affected emission results through addition of fermentable NDF and indirectly through crust formation. Straw bedding contributed $23.0 \%$ of the NDF loaded in the barrels and, therefore, may have contributed to $\mathrm{CO}_{2}$ and $\mathrm{CH}_{4}$ emission. Compared with fecal NDF, straw-bedding NDF likely had higher emission potential because it had not been subjected to enteric fermentation before storage. However, this effect may have been mitigated because straw NDF was in the form of long particles (i.e., minimal processing), resulting in low surface area for microbial fermentation. Furthermore, NDF stratification that occurred with crust formation, a partially aerobic environment, would also reduce the contribution of straw NDF to $\mathrm{CO}_{2}$ or $\mathrm{CH}_{4}$ emission. Formation of a crust may have partially masked potential dietary treatment effects. As found in Aguerre et al. (2012), crust formation had a substantial effect on $\mathrm{NH}_{3}$ emissions after 3 to 4 wk of storage. In the trial reported 

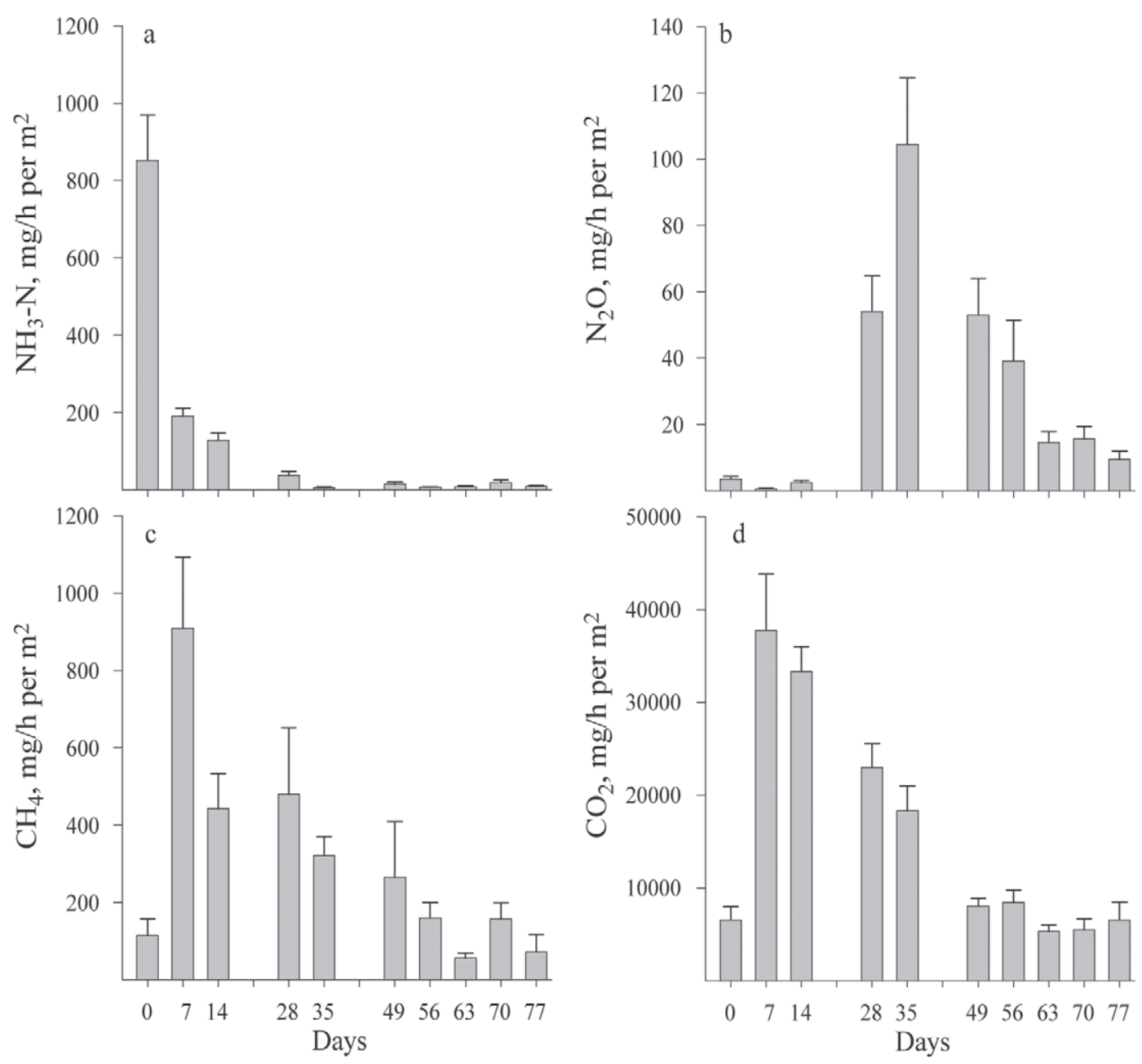

Figure 1. Variation in manure emission rate of (a) $\mathrm{NH}_{3}-\mathrm{N}$, (b) $\mathrm{N}_{2} \mathrm{O}$, (c) $\mathrm{CH}_{4}$, and (d) $\mathrm{CO}_{2}$ throughout the storage period. Error bars indicate standard errors.

here, no dietary effects were observed on $\mathrm{NH}_{3}$ (see above) or $\mathrm{CH}_{4}$ emission before crust formation (which occurred also after 3 to 4 wk of storage), suggesting limited effects of the constant amount of straw-bedding NDF that was part of mixture added to the barrels.

As illustrated by Figure 1c, peak emissions were observed on $\mathrm{d} 7$, and several possible explanations exist for the sharp subsequent decrease in $\mathrm{CH}_{4}$ emission. Once formed, the solid air-dried crust may have acted as a physical barrier affecting gas transport that normally occurs across the aqueous boundary layer exposed to the atmosphere (VanderZaag et al., 2008). Furthermore, the organic crust may have acted as a site for $\mathrm{CH}_{4}$ conversion to $\mathrm{CO}_{2}$ via bacterial oxidation (Petersen et al., 2005). However, as time progressed during storage (after peak emissions), a reduction in $\mathrm{CH}_{4}$ emissions could be associated with changes in manure characteristics (e.g., reduced $\mathrm{pH}$ ) or other fermentation-related parameters associated with methanogenesis.

\section{Carbon Dioxide Emission}

The emission rate of $\mathrm{CO}_{2}$ was not affected by manure treatment. Peak emissions were observed on $d 7$, and then progressively decreased until the end of the study (Figure 1d). Although $\mathrm{CO}_{2}$ emission by cattle manure is not a net contributor to the increase in atmospheric $\mathrm{CO}_{2}$, because the carbon was previously removed from the atmosphere by photosynthesis, it still may have affected the mechanism of emission of other gases. For example, surface crusts started to form on d 7, coincidental with higher emission rates of both $\mathrm{CO}_{2}$ and $\mathrm{CH}_{4}$ (Figure 1c and 1d) that likely carried fiber particles to the surface (Misselbrook et al. 2005).

\section{Rate of C and N Emission}

Results from this study indicated proportionally higher volatile $\mathrm{C}$ loss than volatile $\mathrm{N}$ loss during storage 
with a C:N ratio of 32:1. These results were in agreement with those of Aguerre et al. (2012), suggesting that the C:N ratio in gaseous loss (15:1) was greater than the $\mathrm{C}: \mathrm{N}$ ratio of the manure $(11: 1)$. The higher rate of gaseous $\mathrm{C}: \mathrm{N}$ observed in this study compared with Aguerre et al. (2012) was likely associated with the measurement technique (emission chamber vs. mass balance).

\section{Emission of $\mathrm{CH}_{4}$ and $\mathrm{N}_{2} \mathrm{O}$ as $\mathrm{CO}_{2}$ Equivalents}

Dietary $\mathrm{F}$ :C ratio had no effect on the non- $\mathrm{CO}_{2}$ greenhouse gases emission rate $\left(\mathrm{CH}_{4}+\mathrm{N}_{2} \mathrm{O}\right.$ expressed as $\mathrm{CO}_{2}$ equivalents) from manure (data not shown). However, the relative contributions of $\mathrm{CH}_{4}$ and $\mathrm{N}_{2} \mathrm{O}$ to non- $\mathrm{CO}_{2}$ greenhouse gas emission changed drastically during storage. Between d 0 and 14 of storage, $\mathrm{CH}_{4}$ was by far the main contributor of emitted (mean $\pm \mathrm{SD}) \mathrm{CO}_{2}$ equivalents $(91 \pm 10 \%$ in the first $14 \mathrm{~d}$ of storage; Figure 2). In spite of a decrease in $\mathrm{CH}_{4}$ emissions between d 28 and 35, total emissions of $\mathrm{CO}_{2}$ equivalents continued to increase due to a surge in $\mathrm{N}_{2} \mathrm{O}$ emissions. Finally, from d 49 until the end of the storage period, emissions of $\mathrm{CO}_{2}$ equivalents decreased and $\mathrm{N}_{2} \mathrm{O}$ was the primary source of emissions $(69 \pm 14 \%$, mean $\pm \mathrm{SD})$. These changes in contributions of each gas illustrated the importance of measuring greenhouse gases simultaneously and with long fermentation periods when evaluating treatment responses in manure storage studies.

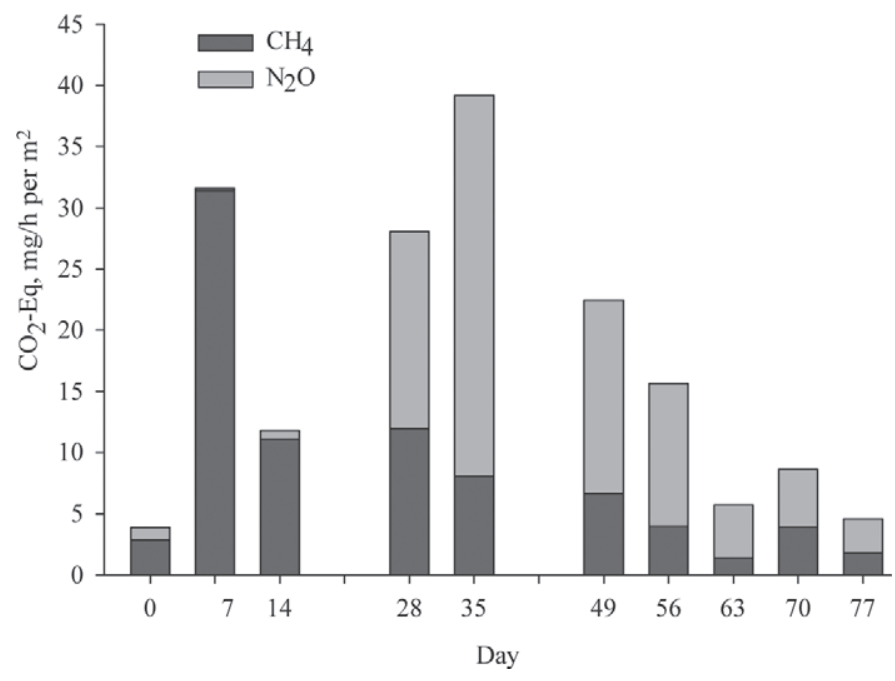

Figure 2. Relative contribution of emitted $\mathrm{N}_{2} \mathrm{O}$ and $\mathrm{CH}_{4}$ to the total non- $\mathrm{CO}_{2}$ greenhouse gas emission during the manure storage period.

\section{CONCLUSIONS}

Together, results of this study and the companion study (Aguerre et al., 2011) suggest that within the 47:53 to 68:32 dietary F:C ratio, dietary treatment effects on enteric $\mathrm{CH}_{4}$ production had no carryover effects during storage. In this trial, dietary $\mathrm{F}$ : $\mathrm{C}$ ratio had no effect on $\mathrm{NH}_{3}-\mathrm{N}, \mathrm{N}_{2} \mathrm{O}, \mathrm{CH}_{4}$, or $\mathrm{CO}_{2}$ emission rate from stored manure. Although changes in fermentation pattern could contribute to reduction in emissions in the long term, an established air-dried crust at the surface of stored manure had a substantial effect on fermentation dynamics and associated emission. Our data suggested that crust formation may have multiple effects on gaseous emission. The crust may act as an emission retardant due to its physical properties. In addition, it may provide a growth environment for bacteria, first promoting those that use $\mathrm{NH}_{3}$ and $\mathrm{CH}_{4}$ as substrate and, thus, acting as a microbial sink for these compounds, but then, in a somewhat sequential manner, promoting microbial growth conducive of $\mathrm{N}_{2} \mathrm{O}$ production and emission. The effects observed in this trial, especially those related to crust formation should not be extrapolated directly to commercial farm conditions, as wind velocity, solar radiation, temperature, precipitation, and other factors may have major effects.

\section{REFERENCES}

Agle, M., A. N. Hristov, S. Zaman, C. Schneider, P. M. Ndegwa, and V. K. Vaddella. 2010. Effect of dietary concentrate on rumen fermentation, digestibility, and nitrogen losses in dairy cows. J. Dairy Sci. 93:4211-4222.

Aguerre, M. J., M. A. Wattiaux, T. Hunt, and N. E. Lobos. 2012. Effect of nitrogen content and additional straw on changes in chemical composition, volatile losses, and ammonia emissions from dairy manure during long-term storage. J. Dairy Sci. 95:3454-3466.

Aguerre, M. J., M. A. Wattiaux, J. M. Powell, G. A. Broderick, and C. Arndt. 2011. Effect of forage-to-concentrate ratio in dairy cow diets on emission of methane, carbon dioxide, and ammonia, lactation performance, and manure excretion. J. Dairy Sci. 94:30813093.

Amon, B., T. Amon, J. Boxberger, and C. Alt. 2001. Emissions of $\mathrm{NH}_{3}, \mathrm{~N}_{2} \mathrm{O}$ and $\mathrm{CH}_{4}$ from dairy cows housed in a farmyard manure tying stall (housing, manure storage, manure spreading). Nutr. Cycl. Agroecosyst. 60:103-113.

Bach Knudsen, K. E. 1997. Carbohydrate and lignin contents of plant materials used in animal feeding. Anim. Feed Sci. Technol. 67:319-338.

Benchaar, C., C. Pomar, and J. Chiquette. 2001. Evaluation of dietary strategies to reduce methane production in ruminants: A modelling approach. Can. J. Anim. Sci. 81:563-574.

Boadi, D., C. Benchaar, J. Chiquette, and D. Massé. 2004. Mitigation strategies to reduce enteric methane emissions from dairy cows: Update review. Can. J. Anim. Sci. 84:319-335.

Broderick, G. A. 2003. Effects of varying dietary protein and energy levels on the production of lactating dairy cows. J. Dairy Sci. $86: 1370-1381$

Chaney, A. L., and E. P. Marbach. 1962. Modified reagents for determination of urea and ammonia. Clin. Chem. 8:130-132.

de Bode, M. J. C. 1991. Odour and ammonia emissions from manure storage. Pages 59-66 in Odour and Ammonia Emissions from Live- 
stock Production. V. C. Nielsen, J. H. Voorburg, and P. L'Hermite, ed. Elsevier Appl. Sci. Publ., London, UK.

EPA (Environmental Protection Agency). 2009. Inventory of U.S. Greenhouse Gas Emissions and Sinks: 1990-2007. EPA, Washington, DC.

FAO (Food and Agriculture Organization of the United Nations). 2006. Livestock's Long Shadow. Environmental issues and options. Accessed June 2, 2011. http://www.fao.org/docrep/010/a0701e/ a0701e00.htm.

Hansen, R. R., D. A. Nielsen, A. Schramm, L. P. Nielsen, N. P. Revsbech, and M. N. Hansen. 2009. Greenhouse gas microbiology in wet and dry straw crust covering pig slurry. J. Environ. Qual. 38:1311-1319.

IPCC (Intergovernmental Panel on Climate Change). 2007. Climate Change 2007: The Physical Science Basis. Contribution of Working Group I to the Fourth Assessment Report of the Intergovernmental Panel on Climate Change. S. Solomon, D. Qin, M. Manning, Z. Chen, M. Marquis, K. B. Averyt, M. Tignor, and H. L. Miller, ed. Cambridge University Press, Cambridge, UK and New York, NY.

Kebreab, E., K. Clark, C. Wagner-Riddle, and J. France. 2006. Methane and nitrous oxide emissions from Canadian animal agriculture: A review. Can. J. Anim. Sci. 86:135-158.

Külling, D. R., H. Menzi, T. F. Kröber, A. Neftel, F. Sutter, P. Lischer, and M. Kreuzer. 2001. Emission of ammonia, nitrous oxide and methane from different types of dairy manure during storage as affected by dietary crude protein content. J. Agric. Sci. 137:235-250

Lascano, G. J., G. I. Zanton, M. L. Moody, P. A. Topper, E. F. Wheeler, and A. J. Heinrichs. 2008. Short communication: Effect of changing the ratio of forage to concentrate on ammonia emissions by dairy heifers. J. Dairy Sci. 91:4301-4306.

Lodman, D. W., M. E. Branine, B. R. Carmean, P. Zimmerman, G. M. Ward, and D. E. Johnson. 1993. Estimates of methane emission from manure of U.S. cattle . Chemosphere 26:189-199.

Martin, C., D. P. Morgavi, and M. Doreau. 2010. Methane mitigation in ruminants: From microbe to the farm scale. Animal 4:351-365.

Misselbrook, T. H., J. M. Powell, G. A. Broderick, and J. H. Grabber. 2005. Dietary manipulation in dairy cattle: Laboratory ex- periments to assess the influence on ammonia emissions. J. Dairy Sci. 88:1765-1777.

Ndegwa, P. M., A. N. Hristov, J. Arogo, and R. E. Sheffield. 2008. A review of ammonia emission mitigation techniques for concentrated animal feeding operations. Biosystems Eng. 100:453-469.

Nielsen, D. A., L. P. Nielsen, A. Schramm, and N. P. Revsbech. 2010 Oxygen distribution and potential ammonia oxidation in floating, liquid manure crusts. J. Environ. Qual. 39:1813-1820.

NRC. 2003. Air emissions from animal feeding operations: Current knowledge, future needs. National Academy of Science, Washington, DC.

Petersen, S. O., B. Amon, and A. Gattinger. 2005. Methane oxidation in slurry storage surface crusts. J. Environ. Qual. 34:455-461.

Rotz, C. A. 2004. Management to reduce nitrogen losses in animal production. J. Anim. Sci. 82(E. Suppl.):E119-E137.

SAS Institute. 2004. SAS/STAT User's Guide. Release 9.2. SAS Inst. Inc., Cary, NC.

Sommer, S. G., S. O. Petersen, and H. T. Søgaard. 2000. Atmospheric pollutants and trace gases: Greenhouse gas emission from stored livestock slurry. J. Environ. Qual. 29:744-751.

Sommer, S. G., G. Q. Zhang, A. Bannink, D. Chadwick, T. Misselbrook, R. Harrison, N. J. Hutchings, H. Menzi, G. J. Monteny, J. Q. Ni, O. Oenema, and J. Webb. 2006. Algorithms determining ammonia emission form buildings housing cattle and pigs and from manure stores. Adv. Agron. 89:261-335.

VanderZaag, A. C., R. J. Gordon, V. M. Glass, and R. C. Jamieson. 2008. Floating covers to reduce gas emissions from liquid manure storages: A review. Appl. Eng. Agric. 24:657-671.

Van Soest, J. P., J. B. Robertson, and B. A. Lewis. 1991. Methods for dietary fiber, neutral detergent fiber, and nonstarch polysaccharides in relation to animal nutrition. J. Dairy Sci. 74:3583-3597.

Wattiaux, M. A., L. D. Satter, and D. R. Mertens. 1991. Effect of source and amount of fiber on kinetics of digestion and specific gravity of forage particles in the rumen. J. Dairy Sci. 74:38723883

Xue, S. K., S. Chen, and R. E. Hermanson. 1999. Wheat straw cover for reducing ammonia and hydrogen sulfide emissions from dairy manure storage. Trans. ASAE 42:1095-1101. 